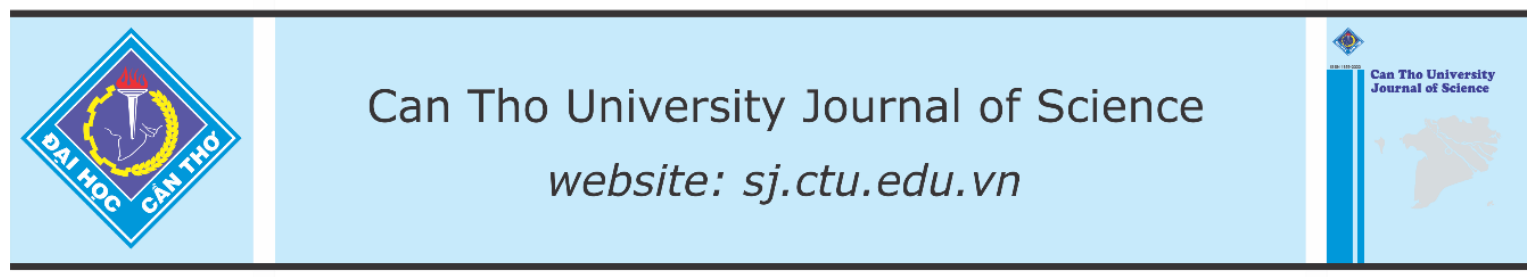

DOI: 10.22144/ctu.jen.2020.026

\title{
Medical malpractice liability insurance: Comparision of Vietnam to some European countries
}

Nguyen Thi Bao Anh*

School of Law, Can Tho University, Vietnam

*Correspondence: Nguyen Thi Bao Anh (email: ntbanh@ctu.edu.vn)

\section{Article info.}

Received 11 Apr 2020

Revised 21 Jun 2020

Accepted 30 Nov 2020

\section{Keywords}

Indemnification, insured risk, medical malpractice liability insurance insured premium, third-party

\begin{abstract}
Medical malpractice liability insurance (MMLI) is one type of professional liability insurance that protects healthcare professionals from liability associated with wrongful practices. This paper analyses and compares the laws of four countries (Belgium, France, England, and Vietnam) on the frameworks of MMLI such as insurable interest, insured risk, insured premium, indemnification, and the third party to find out the similarities and differences of the laws of the four countries and make suggestions to improve the Vietnamese law on MMLI. Comparing the systems of MMLI in Vietnam with the nations is to be aware of the different and similar regulations. The results from this study may help Vietnam to study and improve more about the following rules through the models of MMLI of the countries.
\end{abstract}

Cited as: Anh, N.T.B., 2020. Medical malpractice liability insurance: Comparision of Vietnam to some European countries. Can Tho University Journal of Science. 12(3): 73-79.

\section{INTRODUCTION}

To help medical professionals avoid or/and reduce from the burden of medical malpractice liability, it is indeed imperative that someone came up with a safeguard, and the solution is insurance. Concerning this, professional liability insurance (PLI) has provided a way in which professionals can attempt to protect themselves as well as the parties to whom they offer their services (Kourmatzis, 2009). PLI has become society's chief agency for the distribution of the cost of malpractice in the medical profession. It is quite natural that a medical practitioner is conscious of the possibility of a ruinous malpractice judgment and should seek the protection of insurance. Medical malpractice liability insurance (MMLI) is explicitly designed to protect physicians, hospitals, healthcare facilities, and other health personnel against the financial and legal risks inherent in providing medical care (Victor O. Schinerer \& Company, 2012).

In many countries, MMLI is compulsory for those who are at risk of being sued by third parties for negligence. If an insurance company wants to enter a market where many or most rules are mandatory, it needs to adapt its products to general rule elements (part 2) such as insurable interest, insured risk, insured premium, indemnification. This study will also indicate considerable marks such as the third party's rights, kinds of MMLI in the comparison of MMLI between Vietnam to Belgium, France, and England, the final part (part 3) will conclude the differences between the countries which may help Vietnam to reference for improving its MMLI. 
2 ELEMENTS OF MEDICAL MALPRACTICE LIABILITY INSURANCE IN BELGIUM, FRANCE, ENGLAND AND VIETNAM

\subsection{Insurable interest}

Insurable interest means the policyholder derives pecuniary benefit or advantage by the preservation or continued existence of the property or will sustain a financial loss from its destruction (Fontaine, 2016).

It is defined either in the law or at least in jurisprudence. Some legal systems expressly declare null and void any insurance contract that is concluded without an insurable interest. Others display a more nuanced approach by maintaining an insurance contract void only where the policyholder has insured a non-existent interest to gain an illegal pecuniary benefit thereby. In contrast, some other legal systems lack an insurable interest at the moment of the conclusion of the contract and do not entail such severe consequences (Samothrakis, 2013).

A contract of insurance is one whereby one person promises to compensate another for any loss which the latter might have to suffer on being exposed to certain dangers in consideration of a price known as premium. Thus, it is apparent that a contract of insurance is a contract of indemnity based on the principles of "uberrimae fidei" (utmost good faith) and insurable interest. Insurable interest means that it is an interest that can be or is protected by a contract of insurance (Prashanth, 2008). It is a relationship between the insured and the event insured against such that the occurrence of the event will cause substantial loss or injury of some kind to the insured. Hence, the insurable interest may be defined as an interest of such a nature that the occurrence of the event insured against would cause financial loss to the insured (Rodda, 2008).

In liability insurance, a person has an insurable interest to the extent of any potential liability which may be incurred due to damages and other costs. It is not possible to foretell how much liability or how often a person may incur liability and in what form or shape it arises (Legh et al., 2008).

In Belgium, the existence of a person and legitimate insurable interest is one of the requirements for an insurance contract to be deemed valid. There is an insurable interest where the realisation of an uncertain event leads to a loss suffered by a person or entity. Regarding liability insurance, the insurable interest is the economic or personal interest that the insured has to avoid the realisation of the risk and its consequences (Fontaine, 2016). Article 91 of the Insurance Act of 2014 states that "the insured must demonstrate an economic interest in the preservation of the property or the integrity of the estate" (the King, 2014).

Similar to the rule of the Belgian Insurance Act of 2014, Article L.171-3 of the French Insurance Code also defines insurable interest and the requirements that it has to meet for it to be considered legitimate. The French Civil Code, in Article 6, prohibits all contracts which go contrary to public policy. The existence of insurable interest is not mandatory at the time of conclusion of the contract, but it is necessary to be indicated in the contract. The insurance contract cannot be concluded if the subject-matter insured is already lost before the contract's conclusion as per Articles 1108 and 1126 of the Civil Code (Noussia, 2007).

Under English law, the insurable interest is a right to the property, or a right derivable out of some contract about the property, which in either case may be lost upon some contingency affecting the possession or enjoyment of the property (Chalmers and Owen, 1913). In liability insurance, the subject matter or the property must be precisely defined. Liability insurance is the insurance of the wealth, the "patrimony, of the insured against award(s) of damages. An "insurable interest" is an essential element to a contract of insurance. It has been loosely defined as the insured's pecuniary interest in the subject matter of the insurance. The principle behind the concept of the insurable interest is mainly concerned with ensuring that a person who cannot suffer a loss is prevented from insuring in the first place. The requirement of the insurable interest in a contract of insurance is simply another way of expressing that an insurance contract must be a contract against the risk of loss (Clarke, 2016).

According to Vietnamese law, the insurable interest means a right of ownership, the right of possession, right of use, or a property right, [or] the right and obligation to bring up and support the subject-matter insured (the National Assembly, 2010). Understandably, it is the subject-matter insured in the context of the civil liability of the insured person to a third party as stipulated by the law (the National Assembly, 2010). As mentioned, the insurable interest may be defined as an interest of such a nature that the occurrence of the event insured against would cause financial loss to the insured (Rodda, 2012). Comparing the two concepts, the one regulated in Vietnam 
seems vague. It does not clarify whether, in liability insurance, a person has an insurable interest to the extent of any potential liability which may be incurred due to damage and other costs. In other words, the law does not define whether the insurable interest is to cover the loss of the subject-matter (the third party) on behalf of the insured or not.

Additionally, there is no explanation of "obligation" from Law on Insurance Business However, it is mentioned in Law on Commercial (the National Assembly, 2005). That is the non-breaching party requests the breaching party to properly perform or apply other measures to perform the contract. Possibly, the meaning of "obligation" would be applicable in the context of insurable interest. That is the obligation of the insurer to perform the insurance contract to the insured person.

Similar to the three countries Belgium, France, and England, Vietnam also indicates that a valid insurance policy requires an "insurable intere". Different insurance policies have different insurable interests (the National Assembly, 2010).

\subsection{Insured risk}

The insured risk is "malpractice, error, or mistake in the practice of the insured's profession". Defining the activity from which the liability of the insured arises is essential to all liability insurance. Before there can be any duty of performance of the insurer's promise to defend or indemnify, the insured must have incurred a possible liability for MM (Duke, 1996).

It is generally acknowledged that insurance contracts are concluded to provide cover against specific events, which are primarily regarded as a risk (Samothrakis, 2013). The presence of an element of uncertainty or risk is an essential element of every valid insurance contract. In exchange for the undertaking to pay a premium, the insurer takes over and bears a circumscribed risk of the insured. The risk may be described as the possibility that a specified but uncertain event may occur (Reinecke et al., 2007). It may also refer to the possibility of an undesirable change in the patrimonial circumstances of the insured or as the possibility of harm (Reinecke et al., 2007).

It is repeated that in the absence of any risk, such as when the uncertain event has already taken place or when the object concerning which the insurer has described and taken over the risk has already been destroyed before the conclusion of the relevant insurance, there is no valid insurance contract (Niekerk, 1998).

The provision most commonly used to define the scope of the risk assumed by the professional liability insurer is "malpractice, error or mistake in the practice of the insured's profession." Defining the activity from which the liability of the insured arises is fundamental to all forms of liability insurance before establishing whether there can be any duty of performance of the insurer's promise to defend or indemnify (Basedow, 2009).

In Article 5.14 of the Insurance Act 2014 of Belgium (The King, 2014), the risk is defined as an occurrence in which the insured or the beneficiary has an interest that is not in a proceeding. To be insured, the risk must be: (1) uncertain: the uncertainty may concern either the realization of the event or the moment of such realization; (2) possible: the insurance contract is null and void if the risk does not exist or has already realized itself after the insurance contract; (3) and independent from the will of the insured (Fontaine, 2016). Moreover, Belgian law expresses that the insurance is null and void when the risk does not exist or has already occurred at the time of the conclusion of the contract (the King, 2014).

Similar to Belgium, uncertainty is a crucial element of an insurance contract in French law. France's highest ordinary court, the Cour de Cassation, considers that the uncertainty is the essence of an insurance contract (Cass., 1st Civ. Div., $4^{\text {th }}$ November 2003, appeal on the point of law No 01-14942). The uncertainty in an insurance contract is so significant that, in its absence, either the insurer or the policyholder may see it as a condition to nullify the contract. Professional liability policies are designed for a specific risk - the risk of loss caused by the negligent performance of a professional service provided by designated professionals (Victor O. Schinerer \& Company., INC, 2012).

Similarly, in Belgium and France, a contract of insurance must be a contract based on an uncertain event. Uncertainty relates to the risk of the occurrence of an event, which leads to loss. From a practical point of view, risk managers often make a distinction between risk and uncertainty. The term "risk" is associated with a loss, which can be predicted and therefore insured. On the other hand, uncertainty cannot be predicted and, therefore, cannot be insured. The purpose of this somewhat artificial distinction is to classify and categorise risks and the 
chances of loss associated with the risks (Etzbach, 2013).

In Vietnam, insured events mean objective events mutually agreed upon by the parties or prescribed by law upon the occurrence of which the insurance enterprises shall have to pay the insurance money to the beneficiaries or pay indemnities to the insured (the National Assembly, 2010). There are no more rules to assert that "the occurrence of the insured event" is foreseeable or uncertain. However, an insurable event must be completely random. It is impossible to guarantee an event that will inevitably occur because it is not accidental and therefore, risk transfer will not happen. There is a point outside this rule, which is the risk of death. This risk will undoubtedly occur, but it is still a risk that can be insured. However, the moment of death must be unexpected (Bao Viet Insurance). Although the rule is applicable in insurance, it is not confirmed whether it is applied in MMLI. This point is different from the regulations of Belgium, France, and England, which state that the event must be uncertain.

\subsection{Insured premium}

The premium is the consideration required of the insured, and in return, the insurer undertakes his/her obligation under the contract of insurance. The amount or adequacy of the premium about the risks is a matter for the insurer rather than a court (ec.europa.eu). However, the amount of premium charged might be of help in determining what risks the insurer intended to run if the premium was assessed on a fixed scale commensurate with the scope of risks (Re George and Goldsmiths' Ins, 1899).

In Belgium, the insurance contract specifies the contained element, the amount of the premium, and the manner of determining it must also be specified (the King, 2014).

In France, the premium may be payable at the address of the insured or any other place agreed upon in the cases and terms restrictively set by decree in Conseil d'Etat.

In England, the requirements for payment of a premium are made on a contractual basis. Generally, the requirements for payment of premium will be governed by the terms of the contract of insurance. An insurance contract may contain a premium to be paid at given times (J A Chapman \& Co Limited v Kadirga Denizcilik Ve Ticaret, 1998)

Likewise, in Vietnam, insurance premium means an amount of money that the purchaser of insurance must pay to the insurance enterprise within the timelimit specified and by the method agreed on by the parties in the insurance contract (The National Assembly, 2000). Similar to Belgium, France, and England, the premium rate and the method of paying the premium must be contained in the insurance contract (the National Assembly, 2000).

\subsection{Indemnification}

All forms of insurance can be divided into two categories. One of them is loss or "first-party" insurance; the other is liability or "third-party" insurance. Liability insurance is the protection against the legal judgment or award which could be recovered from the policyholder as a consequence of his injuring or wrongdoing to a third party. "Professionals" are expected by the public to be less prone to error than ordinary people, and the force of law backs this expectation. An insured doctor's malpractice policy protects/covers the doctor concerning the professional acts or omissions defined in the policy in consideration of a specified premium for a specified term. After that, the carrier will protect the doctor against any suit or claim alleging injury or death and on account of which damages are sought. This protection includes the furnishing of legal defence and indemnification to the limits of the policy against any recovery made (American College of Emergency Physicians).

Similar to the standard policy of coverage, Belgian laws also state that the benefit payable by the insurer is limited to the loss suffered by the insured. Such damage may include loss of use of the insured property and loss of profit (The King, 2014). Unless otherwise agreed, benefits payable under a contract of insurance of an indemnity nature shall not be reduced by the benefits payable under a lump-sum insurance contract (the King, 2014).

French law is similar to Belgian law. French law states that a loss means for the purpose of risks mentioned under Article L1142-2 of Public Health Code, any damage or group of damage caused to third parties, engaging the liability of the insured, resulting from one event or group of events, having the same technical cause attributable to the activities of the insured covered by the insurance policy and has given rise to one or several claims (the National Assembly, 2002).

In English law, non-marine insurance recognises only total and partial loss, but there is an intermediate form of loss (Merkin, 2010). The loss must first occur during the period of cover, although the full 
extent of the damage is not yet apparent. If there is no loss during that period, there is no right of recovery (Moore v Evans, 1918).

Compared to the laws of Belgium, France, and England, the law of Vietnam also has the same spirit of indemnification to the third party's loss. For example, the law states that the amount of indemnity which an insurance enterprise shall pay to the insured person shall not exceed the amount of the sum insured unless the insurance contract otherwise provides (the National Assembly, 2010). In addition to the amount of indemnity, an insurance enterprise must also pay to the insured person the necessary and legitimate expenses of taking measures to avoid and minimise loss and damage. Also, the costs arising must be paid, and the insured person must bear to implement instructions from the insurance enterprise (The National Assembly, 2010). Vietnam has regulated MMLI by Decree on Liability insurance for medical examination and treatment (the Government, 2010). This is by specifically applying the same payment principle of the Law on Business Insurance of 2002. The Decree says that on liability insurance, there is the maximum amount to be paid by an insurer for each complaint of coverage. However, it should not exceed the amount of insurance liability for care facilities and treatment as agreed on in the insurance contract. The level of insurance liability, including legal expenses in case of medical establishments, must be paid by the law. The total insurance liability based on medical examination and treatment is the maximum amount an insurer should pay as agreed in the insurance contract. Insurers and medical examination and treatment establishments can arrange the premium and the scope of the liability based on risk assessment of the medical examination and treatment and related factors (The National Assembly, 2011).

On the other hand, some elements under Vietnamese law appear as "extra regulations" compared to the other systems. The rule states that the amount of indemnity which an insurance enterprise must pay to the insured person shall be fixed by the market price at the point of time. Also, in the place where the loss is suffered and on the actual level of loss and damage unless the insurance contract otherwise provides. An explanation for this exception originates from the unstable and unequal market prices in different periods and different areas in Vietnam when assessing the extent of the damage. For example, upon getting treated after a medical incident if the third party went for treatment in a private hospital where fees are higher than in public ones or where fees in big city hospitals are higher than rural area hospitals even though the third party had Social Health Insurance (the Financial Ministry, 2014). The same Article raises another question. That is to say, the cost of price appraisal at market price, and the level of loss and damage shall be borne by the insurance enterprise (the National Assembly, 2010). The author is not at all convinced by this existing rule, yet Vietnam has a law on Price (the National Assembly, 2013). It should take responsibility to price appraise at market price and appraise the level of loss and damage instead of the insurance enterprise. In this opinion, the licensed agency/person who works on price appraisal governed by the Law on Price may objectively ensure the market price and damage's value for the third party as mentioned in the example.

\subsection{Third-party}

In order to facilitate the enforcement of claims for the injured, some Member States (Lyde and Gilbert, 2008), for example, France and Belgium recognise a right of the third party, in general, to directly claim the damage with the insurer although the details differ. In the other Member States, this third party's rights are only exceptionally granted in certain and insufficient cases. Under English Law (Lyde and Gilbert, 2008), there is no common law of right afforded to a third party against the insurer of the person who caused the injury. However, third parties are entitled to compensation under the conditions set out in the third parties (Rights against Insurers) Act of 2010 .

In Belgium, for insurance contracts falling under the Insurance Act 2014, the third parties have a direct legal action right against the liability insurer of the party who caused the damage or loss (the King, 1992). This rule is repeated in Article 50 of the current Insurance Code 2014 of Belgium. All types of loss or damage can be claimed from the liability insurer (physical injury, property damage, or financial loss) and if to the extent that is covered by the policy. Such direct third-party access is granted to all types of non-marine or non-transport liability insurance (e.g. professional liability insurance, contractual liability insurance, and non-contractual liability insurance) (Keulers, 2012).

Equally, French law also accepts that the third-party insured can claim directly under the policy (the National Assembly, 2002). Concerning property damage, there is no statutory right of direct action. Still, case law recognises the right of a third party to claim against the insurer on behalf of the insured. This is 
when the insured fails to do so by way of an action oblique subject to Article 1166 of the Civil Code (Article 1341-1, revised Civil Code). However, the funds recovered are not paid directly to the third party but the insured (Pierre-Olivier, 2017).

Although England does not allow the third party to lay claim for indemnification directly, the new Act has shown that it also protects the third party's rights. Specifically, the Third Party (Rights against Insurers) Act 2010 (the "2010 Act"), finally came into force on $1^{\text {st }}$ August 2016. The 2010 Act makes it easier for a third party to bring a claim against an insurer when the insured party has become insolvent. The 2010 Act will replace the Third Parties (Rights against Insurers) Act of 1930 (the "1930 Act") and is designed to extend and improve the rights of third-party claimants.

Entirely different from Belgium, France, and England, Vietnam's law does not allow the third party to claim for indemnity directly. The law clearly expresses that a third party shall not have the right to directly require an insurance enterprise to indemnify the third party unless otherwise specified by the law (the National Assembly, 2000). The law does not specify any more exceptions for the third party to claim directly. The liability of the insurer only arises if the third party claims an insured person for indemnity, loss, or damage caused by the insured's fault during the duration of the insurance (The National Assembly, 2000). Apparently, the third party's rights are not given enough attention. An excellent example of English law is that the third party can carry out a claim if the insured is in insolvency to make sure that, in the end, the third party's rights are secured.

\section{CONCLUSIONS}

In conclusion, MMLI of the four countries: Belgium, France, England, and Vietnam, contains the same essential elements. However, there are differences among themselves. To make MMLI more comprehend and applicable, Vietnamese law should clarify the meaning "obligation" in the situation of insurable interest other than borrow the definition from another law. Typically, Vietnam does not allow direct third-party claims for indemnification. This restriction keeps the third-party away from claiming for damages satisfactorily if the insurance fails to pay them as his/her expectation. Therefore, it is necessary to allow the third-party claim for indemnification directly.
Moreover, Vietnam does not clarify the rules for protecting the third party's rights once he/she is not satisfied with the compensation. While MMLI has historically existed and developed for an extended period in Belgium, France, and England, MMLI is an obligation, Vietnam has just begun to promote the legislation. It is also more details on professional liability insurance in Law on Insurance Business as well as on the Decree on Liability Insurance in Medical Examination and Treatment. The addition of this regulation aims to create a safe and secure working environment for medical professionals, helping them avoid the risk of financial exhaustion when having to compensate for patients.

\section{REFERENCES}

American College of Emergency Physicians. Medical Professional Liability Insurance, https://www.ohacep.org/aws/OACEP/asset_manager/get_file/32599?ver=567.

Basedow, J. (Ed.), 2009. Principles of European insurance contract law (PEICL). sellier. european law publ.

Chalmers, M. D. E. S., \& Owen, D. (1913). The Marine Insurance Act, 1906. Butterworth. Available from https://lawexplores.com/insurance-act-1906/

Clarke, M., 2016. English Insurance Contract Law (1 ${ }^{\text {st }}$ ed.), bookboon.com, 84 pages.

Duke, J., 1996. Risk Control in Professional Liability Insurance. Duke Law Journal. 106-126,

https://scholarship.law.duke.edu/dlj/vol9/iss1/6.

Etzbach, P. 2013. The Legal Nature of Insurance Contracts. International Bar Association. 1-183. Available from https://www.mannheimerswartling.se/globalassets/publikationer/iba-insurance-substantive-project-2013.pdf

Fontaine, M., 2016. Droit des assurances (Insurance Law). Larcier, 808 pages. Available from https://dial.uclouvain.be/pr/boreal/object/boreal: 173890

JA Chapman \& Co Ltd (In Liquidation) v Kadirga Denizcilik ve Ticaret AS, 1998. Lloyd's Rep. I.R. 377. Available from https://www.ilaw.com/ilaw/doc/view.htm?id=152750.

Keulers, H., 2012. Direct Third-Party Access to Liability Insurance in Belgium, International Bar Association. BA Insurance Committee Substantive Project. https://webcache.googleusercontent.com/search?q=cache:BXKvbnKFzGIJ:https://www.ibanet.org/Document/Default.aspx\%3FDocumentUid\%3D334C288E-984D4870-9905-

192AFF65A398+\&cd=1\&hl=en\&ct=clnk\&gl=vn.

Legh-Jones, N., Birds, J., and et al., 2008. Mac-Gillivray on Insurance Law (11 ${ }^{\text {th }}$ ed). Sweet $\&$ Maxwell, 1412 pages. 
Lyde and Gilbert, 2008. International Comparative Review of Liability Insurance Law. https://www.crowell.com/files/201602-The-International-ComparativeLegal-Guide-To-Insurance-Reinsurance-2016Thorpe-Farrell.pdf.

Merkin, R., 2009. Colinvaux's Law of Insurance ( $9^{\text {th }}$ ed). Sweet \& Maxwell, 304 pages.

Moore v Evans, 1918. AC 185. 193ff.

Niekerk, J., 1998. Assumptions, Risk and the Insurance Contract, SA Merc U, 1-123.

Noussia, K., 2007. The Principle of Indemnity in Marine Insurance Contracts: A Comparative Approach. Springer, 318 pages.

Pierre-Olivier, L., Pauline Arroyo, and Clarence Lefort, et al., 2017. Insurance and Reinsurance in France: Overview. Available from https://uk.practicallaw.thomsonreuters.com/9-501-3248?transitionType $=$ Default $\&$ contextData $=($ sc. De fault) \&firstPage $=$ true

Prashanth, V., 2008. The necessity of Insurable Interest in Insurance Contracts, accessed on 18 November 2008. Available from https://papers.ssrn.com/sol3/papers.cfm?abstract_id=1302372

Rodda, W.H., 2008. Fire and Property Insurance. Available from https://papers.ssrn.com/sol3/Delivery.cfm/SSRN_ID1302372_code941145.pdf?

Reinecke, M. F. B., Van Niekerk, J., and Havenga, P., 2002. General Principles of Insurance Law. LexisNexis Butterworths Durban.

Samothrakis, Y., 2013. Differences in Insurance Contract Laws and Existing EU Legal Framework, Insurance Contract Law - General Part. Available from http://ec.europa.eu/justice/contract/files/expert_groups/report_on_section_3_final_en.pf

The National Assembly, 2009. No. 40/2009/QH12, 23/11/200, Law on Medical Examination and Treatment.

The National Assembly, 2015. No. 91/2015/QH1, Civil Code.

The National Assembly, 2010. No. 24/2000/QH10, Law on Insurance Business.

The National Assembly, 2013. No. 11/2012/QH13, Law on Price.

The National Assembly, No. 36/2005/QH11, Law on Commercial.

The Financial Ministry, 2013. No.17/2013/ND-CP, Circular on Guiding the Implementation of the Government's Decree.

The National Assembly, French Insurance Code, 2002. French law of insurance intermediation mostly originates in transposition of EU Directive 2002/92 of 9 December 2002 on insurance intermediation. The directive was transposed by law no. 2005-1564 of 15 December 2005 and Decree No. 2006-1091 of 30 August 2006, whose provisions have been codified in the French Insurance Code ('FIC').

The King, 2014. No. 2014011239. Belgian Insurance Law. http://www.ejustice.just.fgov.be/cgi_loi/change_lg.pl?language $=$ fr $\&$ la $=F \& c n=2014040423 \&$ table_name $=$ loi

Victor O. Schinerer \& Company., INC, 2012. Intro to Professional Liability Insurance.

https://www.victorinsuranceus.com/risk-mgmt/Documents/UnprotectedFiles/Intro-professional-liability.pdf 